\title{
Identification of ore extraction and metal working in ancient times: a case study of Sagalassos (SW Turkey)
}

\author{
P. Degryse ${ }^{\mathrm{a}, *}$, Ph. Muchez ${ }^{\mathrm{a}}, \mathrm{S} . \mathrm{Six}^{\mathrm{b}}, \mathrm{M}$. Waelkens ${ }^{\mathrm{c}}$ \\ ${ }^{\text {a }}$ Fysico-chemische Geologie, K.U. Leuven, Celestijnenlaan 200C, 3001 Heverlee, Belgium \\ ${ }^{\mathrm{b}}$ Fysische en Regionale Geografie, K.U. Leuven, Redingenstraat 16, 3000 Leuven, Belgium \\ ${ }^{\mathrm{c}}$ Departement Archeologie, K.U. Leuven, M. Theresiastraat 21, 3000 Leuven, Belgium
}

Received 6 May 2002; accepted 25 October 2002

\begin{abstract}
The extensive territory of the ancient (Hellenistic to Byzantine) city of Sagalassos (SW Turkey) offered a rich variety in natural mineral resources. The frequent occurrence of iron slag in the excavations at the site proved the local working of metal. A geochemical prospection campaign was done in the territory of the ancient city in order to identify or discard the city and its territory as a self-sustaining metallurgical centre. Secondly, the geochemical impact of ancient metallurgy was investigated. Geochemical anomalies identified in stream sediments are explained by the presence of mineralised deposits and ancient metal working. $\mathrm{Mg}, \mathrm{Cr}, \mathrm{Co}$ and $\mathrm{Ni}$ anomalies point to chromite and chrysotile-magnetite deposits related to the basic rocks of the Lycian nappes in the area. $\mathrm{Fe}, \mathrm{V}$ and $\mathrm{Ti}$ anomalies indicate the presence of iron mineralisations, which have been worked for iron production in ancient times. Finally, the association of $\mathrm{P}, \mathrm{Cu}, \mathrm{Pb}, \mathrm{Mn}, \mathrm{As}$ and $\mathrm{Ag}$ anomalies are an indicator of human activity at archaeological sites. Within the framework of this geochemical prospection, a metal working site apart from the city of Sagalassos was identified. Here, ore was both extracted and processed to workable iron.

(C) 2002 Elsevier Science B.V. All rights reserved.
\end{abstract}

Keywords: Sagalassos; Roman; Byzantine; Metallurgy; Ore extraction; Geochemical prospection; Archaeometry; Turkey

\section{Introduction}

The archaeology of Sagalassos (SW Turkey, Fig. 1) is the subject of an interdisciplinary research project coordinated by the Katholieke Universiteit Leuven since 1986 (Waelkens et al., 1999). The Hellenistic to Byzantine site is located in the Taurus Mountains of

\footnotetext{
* Corresponding author. Fax: +32-16-327981.

E-mail address: patrick.degryse@geo.kuleuven.ac.be (P. Degryse).
}

southwestern Turkey, within the ancient region of Pisidia. In antiquity, from Hellenistic to early Byzantine times, Sagalassos may not have been much more than a provincial primus inter pares or a regional pole of attraction. However, the systematic and interdisciplinary reconstruction of the ecology and economy of the site and its territory has increased our understanding of the settlement and its inhabitants beyond the traditional aspects of research of classical archaeology in Asia Minor (Waelkens et al., 1999).

Sagalassos appears in the limelight of history in $333 \mathrm{BC}$, when the town and the region of Pisidia were 




Fig. 1. Location of Sagalassos and its territory in SW Turkey and the geology of the Isparta Angle with the main tectonic domains indicated (after Degryse et al., in press). The Bey Dağları platform consists of platform carbonates. The Antalya Nappes, the Sultan Dağ-Beyşhir Nappe and the Lycian Nappe Complex consist of carbonates and ophiolite sheets and were emplaced onto the Bey Dağları platform. The IspartaAntalya area itself is currently dominated by NE-SW extension, which lead to the development of the Aksu Basin.

conquered by Alexander the Great. Thereafter, Pisidia witnessed a sequence of Hellenistic kings, but when the Attalids bequeathed their kingdom to Rome, the region of Pisidia was joined to the Republican province of Asia and later Cilicia. In $25 \mathrm{BC}$, Rome decided to incorporate the region into its empire. The pax Romana introduced by the soldiers of Augustus would last for centuries. The town seems to have remained prosperous for centuries, but its glory is shattered by an early 6th century $\mathrm{AD}$ earthquake. Afterwards, the settlement may have been reduced to the status of a village. The site was largely abandoned after the middle of the 7th century AD, when a dramatic sequel of epidemics, Arab raids and another major earthquake took its toll (Mitchell, 1999, 2000; Waelkens, in press; Waelkens et al., 2000b).
One of the major research topics focussed on unraveling the economic network of the town, on local, regional and supra-regional level. Apart from exploiting the obvious resources such as agriculture and forestry, the extensive territory of Sagalassos offered a rich variety in mineral resources (Degryse et al., in press). The frequent occurrence of iron slag, in several excavation layers dating from the first to the 7 th century $\mathrm{AD}$, proved the continuous working of metal at Sagalassos (Kucha et al., 1995; Degryse, 2001). For this metal industry, several ores of iron, lead and possibly other metals such as copper were used. The ferrous materials found in the city are grouped into slag (waste material) and bloom (an enriched iron product, to be forged into iron objects). Tap slag (suggesting smelting of ores), as well as 
smithing slag, and hearths occur at Sagalassos. The mineralogy of the bloom differs significantly from the slag and this material is the only component that contains a large amount of charcoal and carburized iron. Metallic iron, cohenite, wüstite and charcoal forms about $75 \%$ of the bloom components (Kucha et al., 1995). Other minor constituents are magnetite, larnite, melilite and olivine (fayalite-forsterite). The slag is mainly composed of fayalite. Moreover, kirschteinite and various $\mathrm{Fe}-\mathrm{Ca}$ silicates and $\mathrm{Al}$-silicates are common constituents of the slag, whereas they do not occur in the bloom. Metallic iron, wuestite and magnetite are rare. Complementary to the mineralogical analysis, the bulk chemistry of the slag was determined (Degryse, 2001). This analysis shows that the iron content of the slag is very high, since part of the metal is sacrificed to produce a material in fluid state at $1200{ }^{\circ} \mathrm{C}$ (Cleere, 1976). The high silica and aluminium contents are inherited from the ore, as these elements are drained away in the melting process to form one of the main components of the slag. A melting temperature of about $1200-1300{ }^{\circ} \mathrm{C}$ is obtained from the chemical data and applying the system $\mathrm{FeO}-\mathrm{Al}_{2} \mathrm{O}_{3}-\mathrm{SiO}_{2}$ (after Muan and Osborn, 1965). These temperatures are within the range used in metalworking throughout the Roman world (Cleere, 1976).

Reconnaissance mineral exploration based on the distribution of ore metals in stream sediments is a generally accepted method (Hawkes, 1976). Apart from the geochemical signatures around mineralised areas, trace metals also accumulate at very significant levels on and around ancient sites and this patterning persists up to the present day (Bintliff et al., 1992). Ancient activities such as metallurgy, manuring and 'waste management' have a major geochemical impact on the environment (e.g. Bintliff et al., 1990; Joosten et al., 1998). For instance, lead and copper compounds were used in the elemental form since prehistory, zinc was alloyed with copper, manganese was used in glass production and phosphorous accumulated through manuring (Bintliff et al., 1990). It is known that detailed analysis of these trace metal concentrations provide indications of site function and morphology (Bintliff et al., 1992). Therefore, to further study Sagalassos as a metallurgical centre, a geochemical prospection campaign was set up on its territory.
The first aim of the current campaign was to identify mineralisations on the territory and to identify or discard the city and its territory as a self-sustaining metallurgical centre, i.e. mining ore and processing it to metal. Secondly, the geochemical impact of ancient metallurgy was looked at to determine the constraints for prospection of ancient ore extraction sites. In this respect, the survey has important implications for the identification of specific geochemical signatures left by the ancient inhabitants of a territory. The characterisation of such geochemical signals can be used in future studies to assess whether a locality or a position in the stratigraphy was inhabited or worked in ancient times. Such information will be most valuable for further archaeological surveying and the reconstruction of ancient agriculture and land use.

\section{Geology and geomorphology}

\subsection{Tectonic setting}

The area studied is part of the so-called Isparta Angle in southwestern Turkey (Fig. 1). The complex amalgamation history of continental and oceanic slivers, indicating a progressive evolution from continental rifting and passive margin development to ocean basin formation during Triassic to late Cretaceous time, resulted in a particular triangular-shaped configuration (Dilek and Rowland, 1993). Regional compression began in the latest Cretaceous (Maastrichtian) and led to subduction-accretion. The Antalya Nappes were emplaced towards the north onto the Bey Dağları carbonate platform in the latest Cretaceous-Palaeocene time. In the late Eocene, the platform was overthrusted from the northeast by the Sultan Dağ-Beyş ehir Nappe Complex. The Lycian Nappe Complex was emplaced onto the Bey Dağları platform from the northwest during the late Miocene. Crustal extension and strike-slip faulting characterise the Isparta Angle suture zone during the Plio-Quaternary, with the development of the north-south oriented Kovada graben (Robertson, 1993). The territory of Roman Sagalassos is situated in the frontal area of the Lycian Nappe Complex on the western limb of the Isparta Angle. 


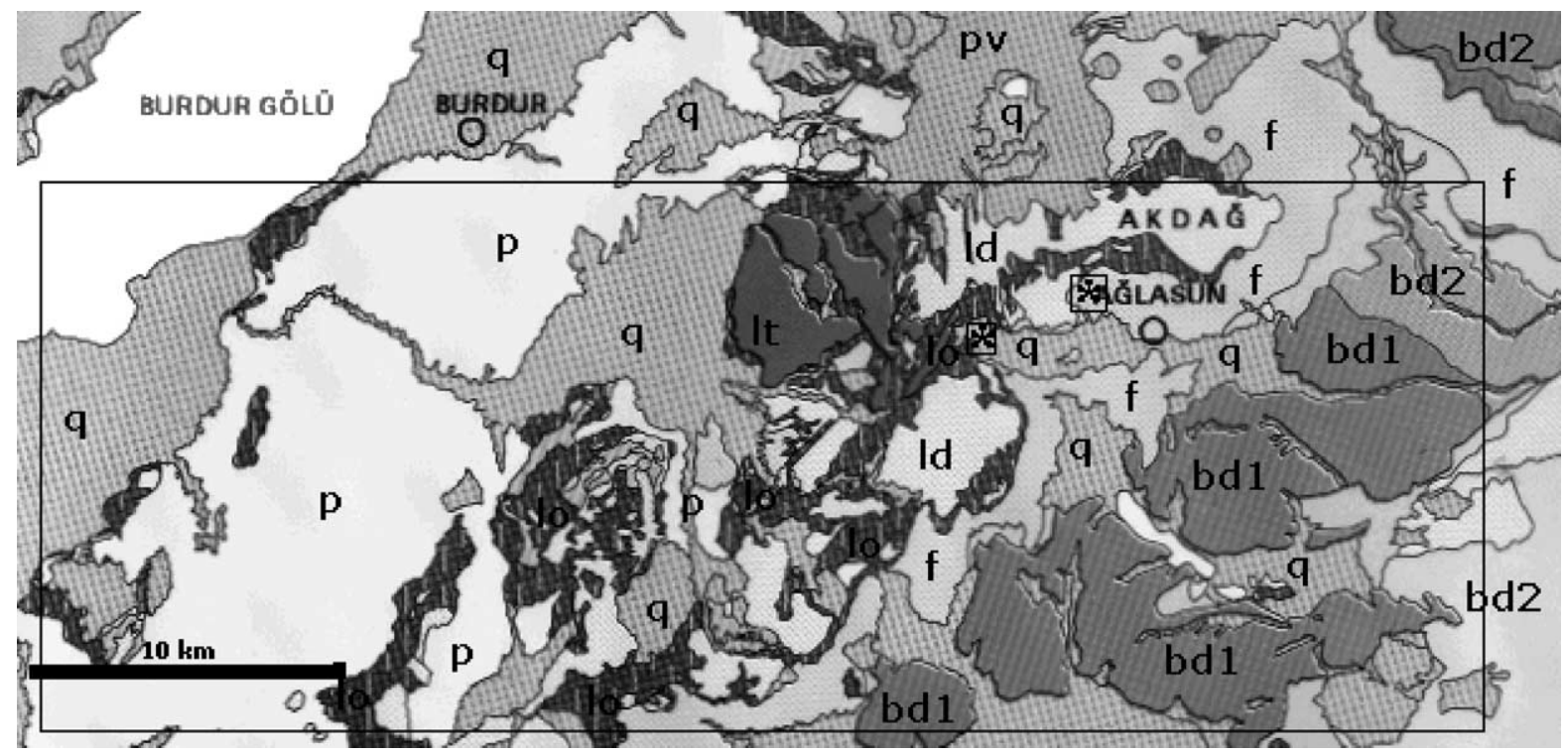

Fig. 2. The territory of Sagalassos, with the major geological units indicated. The frame indicates the approximate area of geochemical prospection in the territory (area shown in Figs. 3, 8 and 9). Map after MTA (1997). q: Quaternary lake sediments; p: Pliocene sediments; pv: Pliocene volcanics; lo: Lycian nappes ophiolite (Marmaris nappe); lt: Lycian nappes, upper limestone (Tavaş nappe); ld: Lycian nappes, lower limestone (Domuzdağ nappe); f: flysch; bd1: autochthonous limestone; bd2: autochthonous limestone and siliciclasts. Scale bar is $10 \mathrm{~km}$, known mineralisations are indicated with an asterisk.

\subsection{Stratigraphy}

The Bey Dağları platform consists of Triassic to lower Jurassic (Liassic) shallow water limestones and dolomites up to $200 \mathrm{~m}$ thick, overlain by a sequence of neritic limestones (1500 m thick) of Dogger to Cenomanian age (Poisson et al., 1984). Pelagic limestones with ages between Turonian and late Palae-

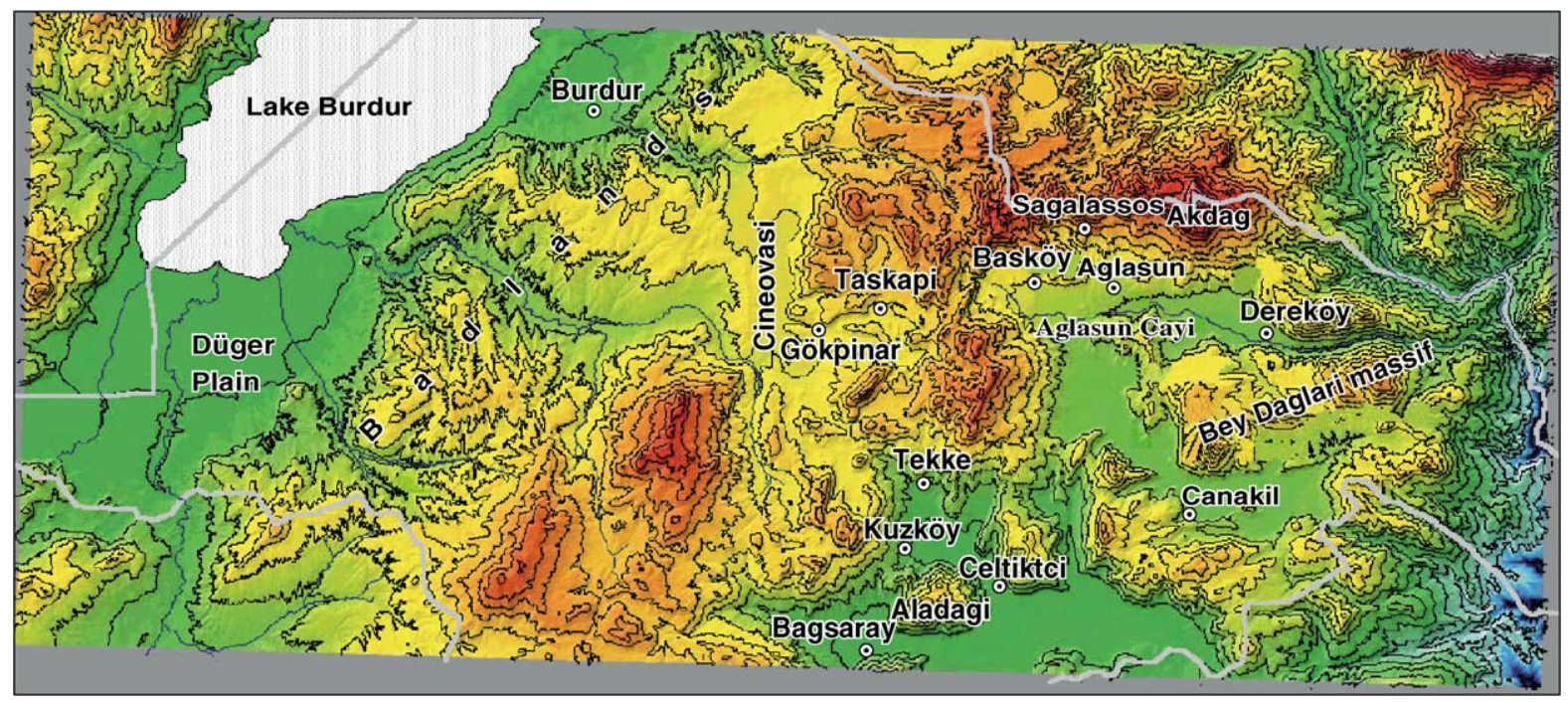

Fig. 3. Geomorphological setting of the territory of Sagalassos, area indicated in Fig. 2. 
Table 1

Basic statistics of the geochemical data of the territory of Roman Sagalassos

\begin{tabular}{|c|c|c|c|c|c|c|c|c|c|c|c|c|c|c|c|c|}
\hline Statistics & $\begin{array}{l}\mathrm{Mg}, \\
\% \\
\end{array}$ & $\begin{array}{l}\mathrm{Al}, \\
\%\end{array}$ & $\begin{array}{l}\mathrm{Fe}, \\
\%\end{array}$ & $\begin{array}{l}\mathrm{P}, \\
\mathrm{ppm}\end{array}$ & $\begin{array}{l}\mathrm{Ti}, \\
\mathrm{ppm}\end{array}$ & $\begin{array}{l}\mathrm{V}, \\
\mathrm{ppm}\end{array}$ & $\begin{array}{l}\mathrm{Cr}, \\
\mathrm{ppm}\end{array}$ & $\begin{array}{l}\mathrm{Mn}, \\
\mathrm{ppm}\end{array}$ & $\begin{array}{l}\text { Co, } \\
\text { ppm }\end{array}$ & $\begin{array}{l}\mathrm{Ni}, \\
\mathrm{ppm}\end{array}$ & $\begin{array}{l}\mathrm{Cu}, \\
\mathrm{ppm}\end{array}$ & $\begin{array}{l}\mathrm{Zn}, \\
\mathrm{ppm}\end{array}$ & $\begin{array}{l}\text { As, } \\
\text { ppm }\end{array}$ & $\begin{array}{l}\mathrm{Cd}, \\
\mathrm{ppm}\end{array}$ & $\begin{array}{l}\mathrm{Pb}, \\
\mathrm{ppm}\end{array}$ & $\begin{array}{l}\mathrm{Ag}, \\
\mathrm{ppm}\end{array}$ \\
\hline$n$ Samples & 117 & 117 & 117 & 117 & 117 & 117 & 117 & 117 & 117 & 117 & 117 & 117 & 81 & 49 & 95 & 1 \\
\hline Minimum & 0.1 & 0.1 & 1.5 & 61 & 10 & 20 & 13 & 364 & 6 & 13 & 16 & 40 & 1 & 0.1 & 1 & 0.2 \\
\hline Maximum & 21.3 & 4.5 & 6.1 & 7615 & 8109 & 237 & 582 & 3048 & 99 & 1648 & 126 & 305 & 18 & 1.6 & 222 & 0.2 \\
\hline Median & 1.7 & 2.5 & 3.4 & 801 & 1009 & 59 & 87 & 922 & 20 & 108 & 43 & 80 & 5 & 0.1 & 13 & - \\
\hline Mean & 2.6 & 2.4 & 3.4 & 1222 & 1449 & 68 & 102 & 1021 & 24 & 174 & 46 & 91 & 6 & 0.2 & 23 & - \\
\hline Standard deviation & 2.8 & 0.8 & 1.0 & 1417 & 1306 & 34 & 74 & 456 & 13 & 248 & 18 & 34 & 3 & 0.3 & 28 & - \\
\hline Variance & 8.0 & 0.7 & 1.1 & $2,010,000$ & $1,700,000$ & 1146 & 5520 & $2,080,000$ & 166 & 61477 & 315 & 1171 & 10 & 0.1 & 800 & - \\
\hline
\end{tabular}

ocene stratigraphically overlie the neritic limestones (Dilek and Rowland, 1993), while Upper Palaeocene to Lower Eocene olistostrome deposits, containing ophiolitic material, rest on these pelagic limestones. These olistostromes are overlain by neritic Lutetian limestones (Poisson, 1977). A sequence of neritic limestones of Aquitanian age, turbiditic flysch (Burdigalian) and deltaic conglomerates (Langhian) formed on top of the Eocene deposits (Poisson et al., 1984). The Mesozoic ophiolitic, sedimentary and volcanic rocks within the Isparta Angle are part of the Antalya, Beyşehir and Lycian Nappe Complexes, all of which tectonically rest on the autochthonous platform carbonates (Dilek and Rowland, 1993). They present a large variety of units, consisting of shallow water carbonates, radiolarites, limestone breccias, limestones with chert, dolomites, fine-grained siliciclastics with ophiolitic material and an ophiolitic mélange consisting of a chaotic sequence of ophiolitic material, radiolarites and pillow lavas (Degryse et al., in press; Muchez et al., in press). The flysch of Burdigalian age consists of an alternation of sand-
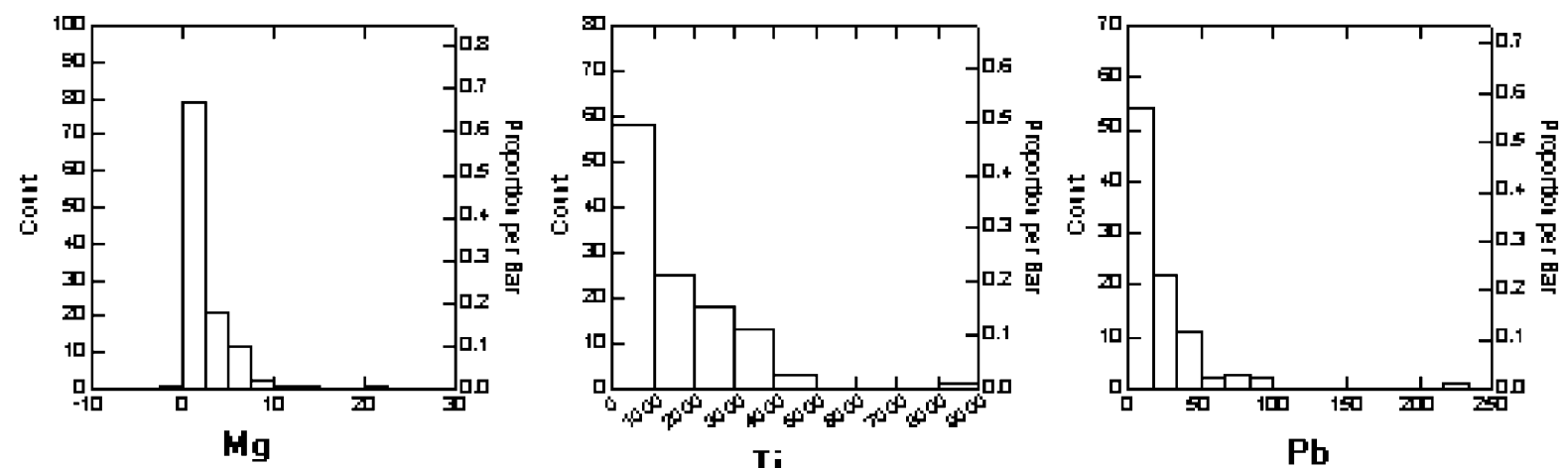

$\mathrm{Ti}$
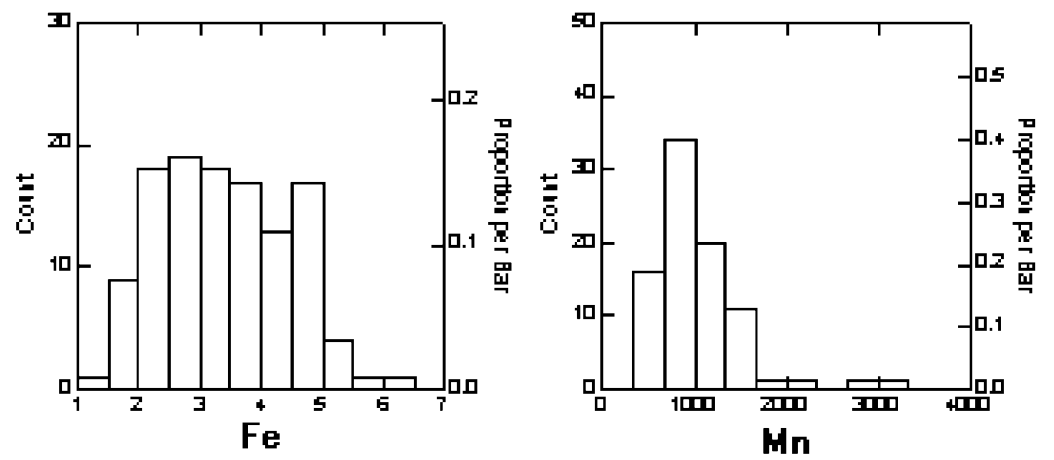

Pb

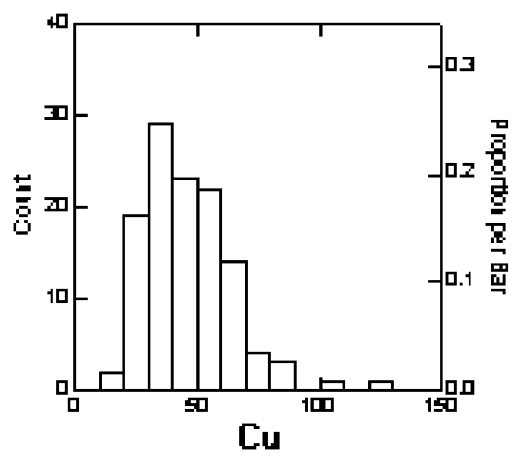

Fig. 4. Histograms of selected geochemical data gathered in the geochemical study of the territory of Roman Sagalassos. 
Table 2

Thresholds calculated for the different major geological units on the territory of Roman Sagalassos

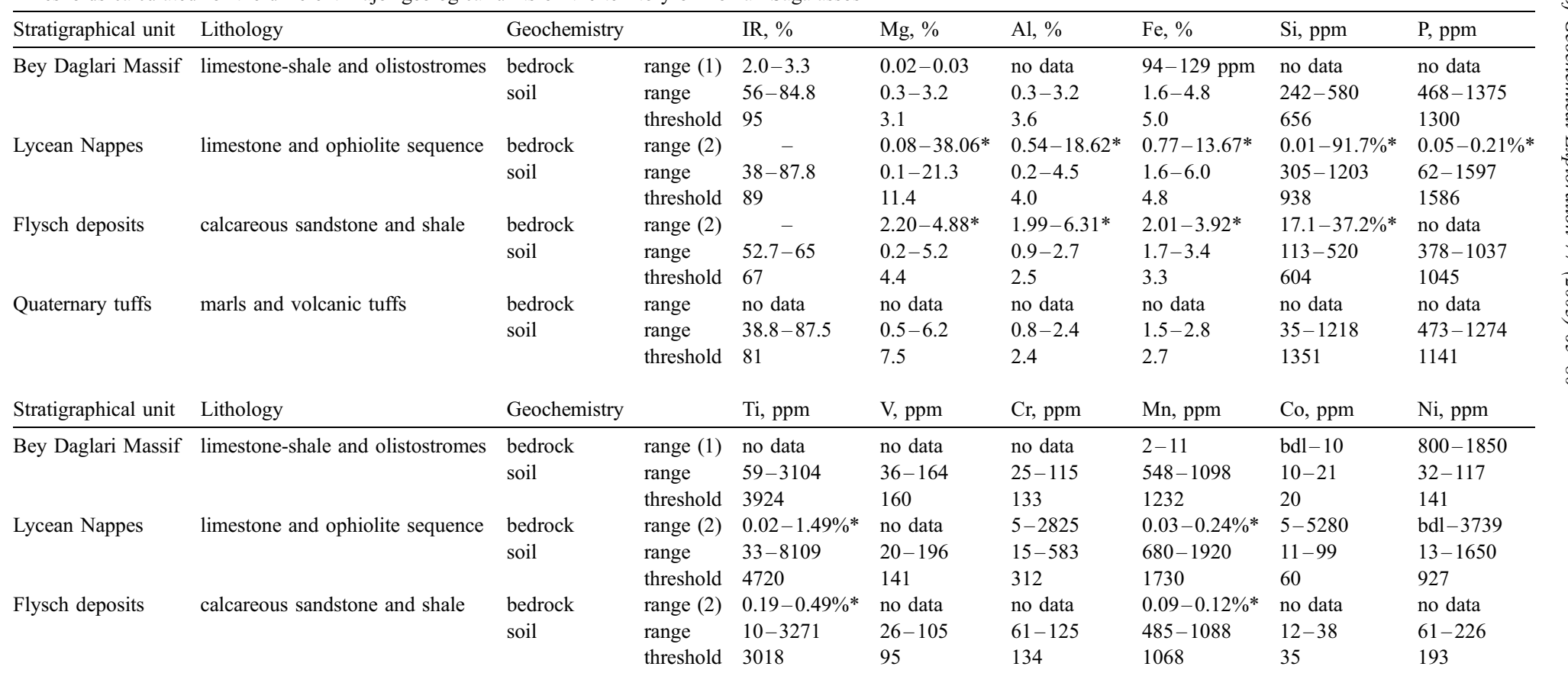

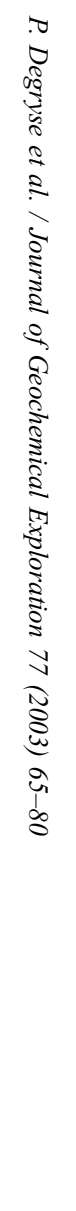




\begin{tabular}{|c|c|c|c|c|c|c|c|c|c|}
\hline Quaternary tuffs & marls and volcanic tuffs & $\begin{array}{l}\text { bedrock } \\
\text { soil }\end{array}$ & $\begin{array}{l}\text { range } \\
\text { range } \\
\text { threshold }\end{array}$ & $\begin{array}{l}\text { no data } \\
247-3297 \\
3040\end{array}$ & $\begin{array}{l}\text { no data } \\
48-90 \\
86\end{array}$ & $\begin{array}{l}\text { no data } \\
13-139 \\
152\end{array}$ & $\begin{array}{l}\text { no data } \\
364-979 \\
1124\end{array}$ & $\begin{array}{l}\text { no data } \\
6-21 \\
23\end{array}$ & $\begin{array}{l}\text { no data } \\
21-164 \\
189\end{array}$ \\
\hline Stratigraphical unit & Lithology & Geochemistry & & $\mathrm{Cu}, \mathrm{ppm}$ & $\mathrm{Zn}, \mathrm{ppm}$ & As, ppm & $\mathrm{Cd}, \mathrm{ppm}$ & $\mathrm{Pb}, \mathrm{ppm}$ & Ag, ppm \\
\hline Bey Daglari Massif & limestone-shale and olistostromes & $\begin{array}{l}\text { bedrock } \\
\text { soil }\end{array}$ & $\begin{array}{l}\text { range (1) } \\
\text { range } \\
\text { threshold }\end{array}$ & $\begin{array}{l}\text { bdl } \\
20-64 \\
57\end{array}$ & $\begin{array}{l}\text { bdl-2600 } \\
57-137 \\
145\end{array}$ & $\begin{array}{l}\text { no data } \\
7-12 \\
11\end{array}$ & $\begin{array}{l}\text { bdl } \\
\text { bdl }-0.2 \\
0.3\end{array}$ & $\begin{array}{l}\text { bdl } \\
8-43 \\
50\end{array}$ & $\begin{array}{l}\text { bdl } \\
\text { bdl } \\
\end{array}$ \\
\hline Lycean Nappes & limestone and ophiolite sequence & $\begin{array}{l}\text { bedrock } \\
\text { soil }\end{array}$ & $\begin{array}{l}\text { range (2) } \\
\text { range } \\
\text { threshold }\end{array}$ & $\begin{array}{l}\text { bdl-10,140 } \\
16-74 \\
71\end{array}$ & $\begin{array}{l}\text { bdl-20,010 } \\
45-305 \\
167\end{array}$ & $\begin{array}{l}\text { no data } \\
\text { bdl- } 18 \\
8\end{array}$ & $\begin{array}{l}\text { no data } \\
\text { bdl }-1.6 \\
1.1\end{array}$ & $\begin{array}{l}\text { bdl-1756 } \\
1-99 \\
52\end{array}$ & $\begin{array}{l}\text { bdl } \\
\text { bdl } \\
\quad\end{array}$ \\
\hline Flysch deposits & calcareous sandstone and shale & $\begin{array}{l}\text { bedrock } \\
\text { soil }\end{array}$ & $\begin{array}{l}\text { range (2) } \\
\text { range } \\
\text { threshold }\end{array}$ & $\begin{array}{l}\text { no data } \\
21-66 \\
67\end{array}$ & $\begin{array}{l}\text { no data } \\
40-87 \\
92\end{array}$ & $\begin{array}{l}\text { no data } \\
\text { bdl }-7 \\
8\end{array}$ & $\begin{array}{l}\text { no data } \\
\text { bdl }-0.2 \\
0.1\end{array}$ & $\begin{array}{l}\text { no data } \\
2-13 \\
15\end{array}$ & $\begin{array}{l}\text { no data } \\
\text { bdl } \\
\quad\end{array}$ \\
\hline Quaternary tuffs & marls and volcanic tuffs & $\begin{array}{l}\text { bedrock } \\
\text { soil }\end{array}$ & $\begin{array}{l}\text { range } \\
\text { range } \\
\text { threshold }\end{array}$ & $\begin{array}{l}\text { no data } \\
24-56 \\
51\end{array}$ & $\begin{array}{l}\text { no data } \\
50-271 \\
209\end{array}$ & $\begin{array}{l}\text { no data } \\
3-19 \\
15\end{array}$ & $\begin{array}{l}\text { no data } \\
0-0.1 \\
0.1\end{array}$ & $\begin{array}{l}\text { no data } \\
4-27 \\
21 \\
\end{array}$ & $\begin{array}{l}\text { no data } \\
\text { bdl } \\
\quad-\end{array}$ \\
\hline \multicolumn{10}{|c|}{$\begin{array}{l}\text { bdl: Below detection limit. } \\
\text {-: Irrelevant, not calculated. } \\
\text { *: Analysed as oxides. } \\
\text { (1): Analysed with AAS after dissolution in } 1 \mathrm{~N} \mathrm{HCl} \text {. } \\
\text { (2): Analysed with AAS/AES after fusion with lithiummetaborate and total dissolution in } \mathrm{HNO}_{3} \text {. } \\
\text { IR: insoluble residue. }\end{array}$} \\
\hline
\end{tabular}


stones and shales with some conglomerate levels. This sequence is very rich in lime. The flysch is the result of the infill of a Miocene flexural foreland basin in front of the advancing Lycian Nappe Complex.
Alluvial, lacustrine and volcanic deposits form the upper part of the stratigraphy. The alluvial and lake deposits are mainly composed of clays, but also pebbles, gravel, travertine and volcanic tuffs occur. The volcanic tuffs are of Miocene to Pliocene age and the

Table 3

Anomalous samples identified after standardising the geochemical data to the thresholds calculated (values in percentages: \% anomalous)

\begin{tabular}{|c|c|c|c|c|c|c|c|c|c|c|c|c|c|c|c|}
\hline Sample & $\mathrm{Mg}$ & $\mathrm{Fe}$ & $\mathrm{P}$ & $\mathrm{Ti}$ & $\mathrm{V}$ & $\mathrm{Cr}$ & $\mathrm{Mn}$ & Co & $\mathrm{Ni}$ & $\mathrm{Cu}$ & $\mathrm{Zn}$ & As & $\mathrm{Ag}$ & $\mathrm{Cd}$ & $\mathrm{Pb}$ \\
\hline \multicolumn{16}{|l|}{$\mathrm{Mg}-\mathrm{Cr}-\mathrm{Co}-\mathrm{Ni}$} \\
\hline SA 01 PDS 18 & 87 & & & & & 87 & & 65 & 78 & & & & & & \\
\hline SA 00 PDS 7 & 17 & & & & & 14 & & 20 & 75 & & & & & & \\
\hline SA 00 PDS 11 & & 10 & & & & 13 & & & 35 & & & & & & \\
\hline \multicolumn{16}{|l|}{$\mathrm{Fe}-\mathrm{Ti}-\mathrm{V}$} \\
\hline SA 00 PDS 15 & & & & & 24 & & & & & & & 125 & & & \\
\hline SA 00 PDS 18 & & & & 72 & 39 & & & & & & & & & & \\
\hline SA 00 PDS 20 & & & & & 21 & & & & & & & & & & \\
\hline \multicolumn{16}{|l|}{$P-C u-P b-A s$} \\
\hline SA 99 PDC 12 & & & 300 & & & & & & & & & & & & \\
\hline SA 99 PDC 15 & & & 208 & & & & & & & & & & & & \\
\hline SA 99 PDC 17 & & & 280 & & & & & & & 77 & & 19 & & & 326 \\
\hline SA 99 PDC 18 & & & 339 & & & & & & & 19 & & 31 & & & 32 \\
\hline SA 99 PDC 23 & & & 262 & & & & & & & & & 13 & $*$ & & 29 \\
\hline SA 98 PDG 9 & & & 124 & & & & & & & 47 & & & & & 32 \\
\hline SA 98 PDG 16 & & & 144 & & & & & & & 13 & & & & & \\
\hline
\end{tabular}

$\mathrm{Mg}-\mathrm{Cr}-\mathrm{Co}-\mathrm{Ni}$ and $\mathrm{P}-\mathrm{Cu}-\mathrm{Pb}-\mathrm{As}$

SA 01 PDS 25

SA 01 PDS 54

SA 01 PDS 55

SA 96 PS 3

SA 96 PS 4

SA 96 PS 5

SA 97 AC 53

SA 97 AC 54

SA 97 AC 55

SA 97 AC 57

SA 97 AC 58

SA 97 AC 59

SA 97 AC 62

SA 97 AC 63

Zn

SA 01 PDS 36

Cd

SA 00 PDS 35 36

17

147

$80 \quad 72$

$\begin{array}{lll}35 & 38 & 26\end{array}$

$87 \quad 43 \quad 28$

12

24

$\begin{array}{lll} & 63 & 27 \\ 11 & 48 & 12 \\ & 13 & \end{array}$

139

17

31
26

29

32

$\mathrm{Cu}$

SA 00 EP 183

*: Ag above detection limit. 
alluvial and lake deposits of Quaternary age (Poisson, 1975; Robertson, 1993).

\subsection{Mineralisations}

On the territory of Sagalassos, two major mineralisation types were identified in previous surveys (Fig. 2; Degryse, 2001). One type occurs in the limestone nappe of the Lycian Complex and the other within the ophiolitic mélange of this complex. The first type is present around the city of Sagalassos and shows occurrences of massive pyrolusite $\left(\mathrm{MnO}_{2}\right)$, of disseminated magnetite $\left(\mathrm{Fe}_{3} \mathrm{O}_{4}\right)$ and hausmannite $(\mathrm{Mg}$, $\mathrm{Fe})(\mathrm{Al}, \mathrm{Fe}, \mathrm{Cr})_{2} \mathrm{O}_{4}$ with halloysite and of hematite $\left(\mathrm{Fe}_{2} \mathrm{O}_{3}\right)$, all associated with quartz. On the pass from
Başköy to Taşkapı (Figs. 2 and 3), in the same Lycian limestone nappe, a similar mineralisation of magnetite and hausmannite but associated with clinochlore, talc, tremolite and quartz was identified. Within the tectonised ophiolite sequence, the second mineralisation type occurs. It consists of magnetite, chromite $\left(\mathrm{FeCr}_{2} \mathrm{O}_{4}\right)$ and magnesiochromite $\left(\mathrm{MgCr}_{2} \mathrm{O}_{4}\right)$ associated with chrysotile.

\subsection{Geomorphology and climate}

The territory of Sagalassos is situated in the SSWNNE mountain ranges of the Western Taurus. Altitudes on the territory vary between $\sim 800$ and $\sim 2000 \mathrm{~m}$ a.s.l. An oro-mediterranean climate with
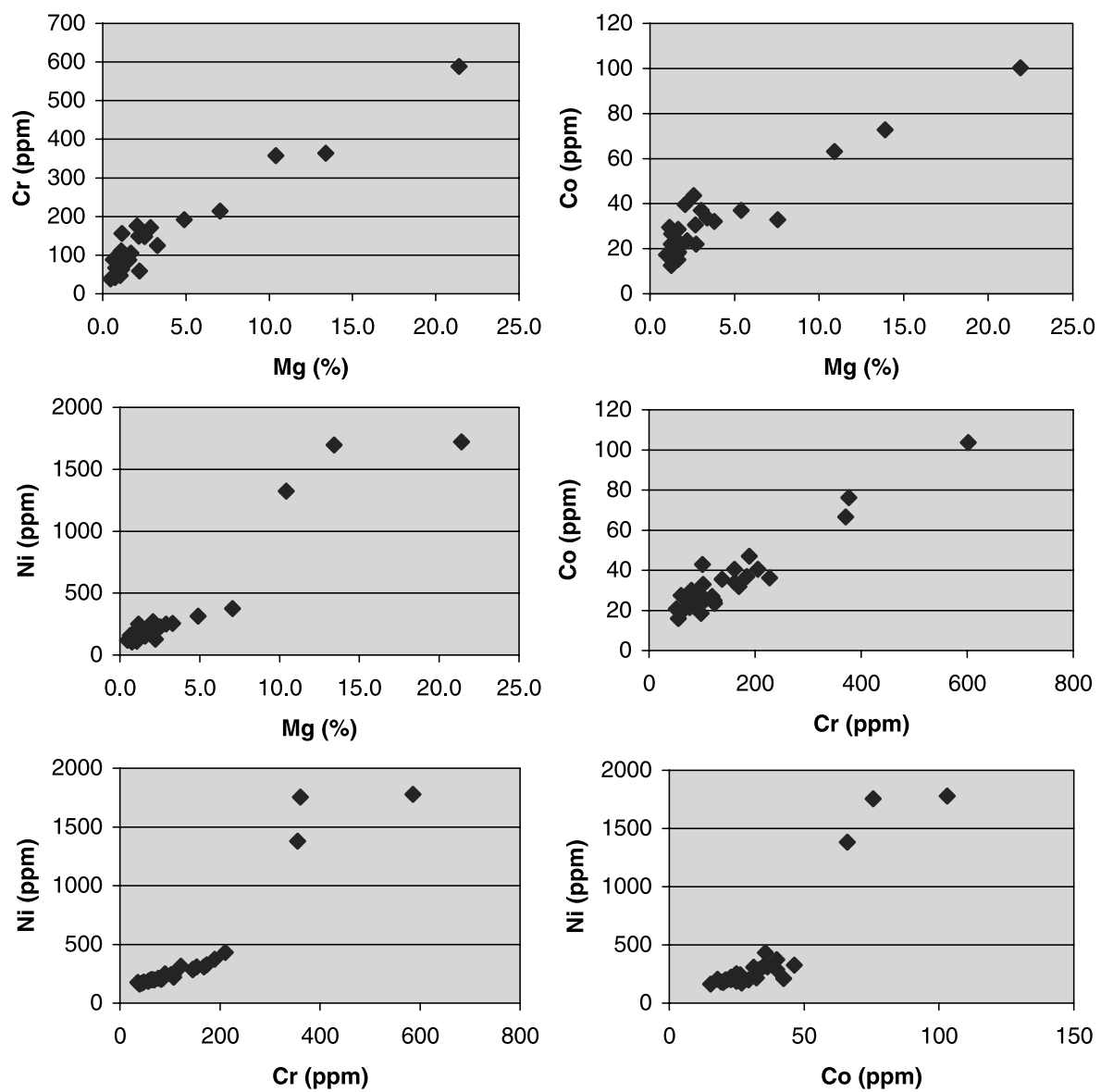

Fig. 5. Biplots for $\mathrm{Mg}, \mathrm{Cr}$, Co and $\mathrm{Ni}$ of the anomalous samples identified on the territory of Roman Sagalassos. 
a subhumid and cold to very cold character prevails, characterised by a short, warm and dry summer and a cold winter with pronounced precipitation (Paulissen et al., 1993). Mean annual temperature and precipitation are $10.7{ }^{\circ} \mathrm{C}$ and $844.2 \mathrm{~mm}$ for Ağlasun $(1150 \mathrm{~m}$ a.s.1.). Sagalassos and its surroundings are located in the oro-mediterranean vegetation zone (van Zeist et al., 1975). This vegetation belt is subdivided into two units. The lower unit present between 800 and $1200 \mathrm{~m}$ is characterised by conifer forests of Pinus brutia, maquis and woodland of deciduous oak trees. The natural vegetation of the upper unit between 1200 and $2000 \mathrm{~m}$ is often deforested and degraded and is characterised by Cedrus libani, Pinus nigra and Abies cilicica.

The geomorphology and topography of the territory of Sagalassos (Fig. 3) were described in detail in the context of the intense archaeological surveys by Waelkens et al. (1997) for the central and eastern part of the territory and by Waelkens et al. (2000a) for the western part of the territory. The geomorphology of the territory is strongly related to its geological structure. The westernmost part of the territory is the plain of Burdur. Lake Burdur (854 m a.s.l.) fills the largest part of this plain. It is part of a graben structure between two southwest-northeast running faults. The Düğer plain, located south of the lake, has a complex morphology and is composed of lacustrine sediments from the Burdur lake and fluvial sediments, deposited as alluvial fans or lacustrine deltas (Kazanci and Erol, 1987). Lake Burdur and the surrounding plains are separated by a pronounced scarp from an undulating plateau of eroded marls. Here, a complex badland morphology was developed. In the southwest of the territory two NNE-SSW mountain ridges occur. These limestone massifs are an important barrier and form a valuable source of water. An elongated northsouth orientated plateau at an elevation of ca. $1200 \mathrm{~m}$ a.s.l., i.e. the Çineovası separates these ridges from a rolling topography of bare limestone hills and mountain valleys to the east. North of the village of Ağlasun, the allochthonous limestone forms a cuesta at an elevation of ca. $2000 \mathrm{~m}$ a.s.l., ending in the Akdağ mountain (2271 $\mathrm{m}$ a.s.1.). It is near this cuesta front that Sagalassos was built. The Ağlasun Çayı flows south of this cuesta in a valley bordered by flysch deposits. A rolling topography with gentle and convex slopes characterises the flysch landscape.
Downstream, near the village of Dereköy, the Ağlasun Çayı cuts through the limestone of the Bey Dağları Massif and flows into the north-south orientated Isparta Çayı that forms the eastern boundary of the territory. Surrounded by limestone hills of the Bey Dağları Massif, two large plains formed, i.e. the plain of Çanaklı and the plain near Çeltiktçi and Bağsaray.

\section{Methodology}

On the territory of Sagalassos, over an area of 1500 $\mathrm{km}^{2}, 110$ samples of fresh stream sediments were taken. A virtual grid of $4 \times 4 \mathrm{~km}$ frames was projected on the territory. At least one stream sediment sample was taken in each frame of the grid. Seven samples were taken from drill cores through the stratigraphy of the fill of a small pond in the city of Sagalassos. Sample weight was approximately $200 \mathrm{~g}$. All samples were sieved to the 80-mesh size fraction. One gram of
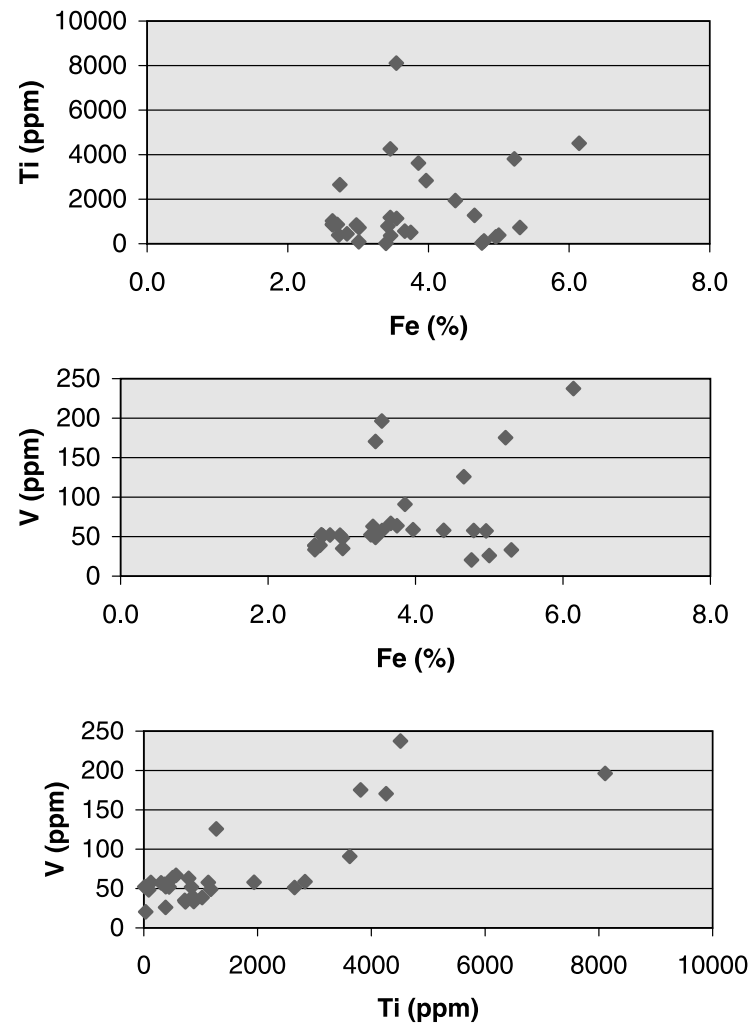

Fig. 6. Biplots for Fe, Ti and V of the anomalous samples identified on the territory of Roman Sagalassos. 

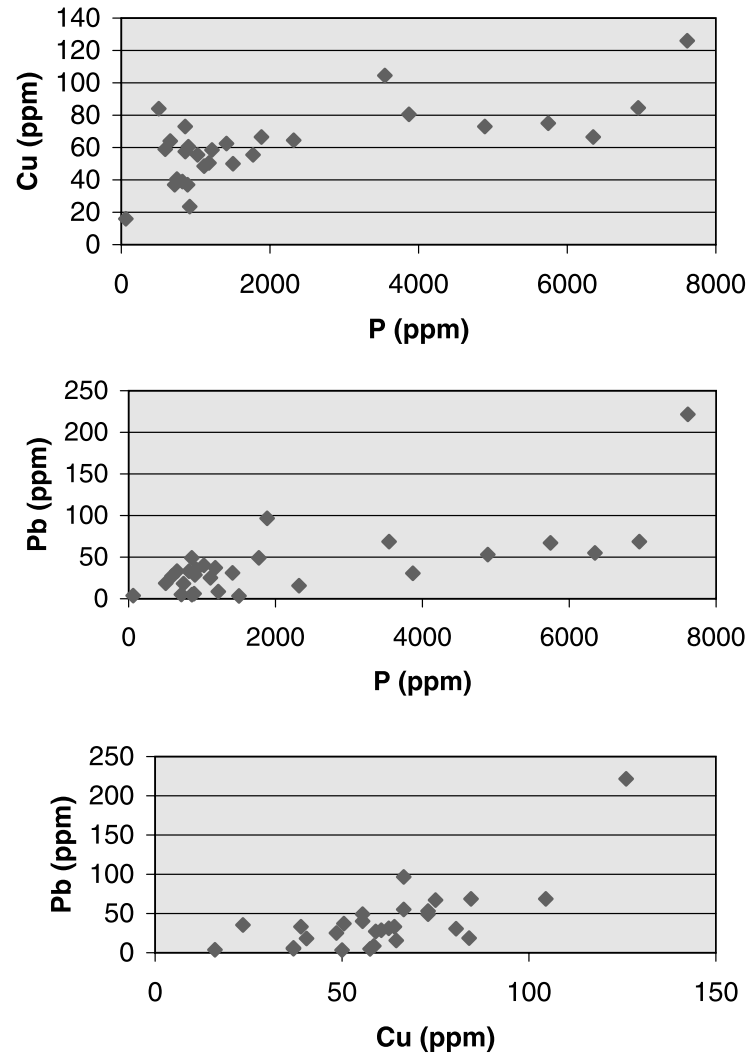

Fig. 7. Biplots for $\mathrm{P}, \mathrm{Pb}$ and $\mathrm{Cu}$ of the anomalous samples identified on the territory of Roman Sagalassos.

each sieved sample was digested into $20 \mathrm{ml}$ of aqua regia (15 ml $\mathrm{HCl}_{\text {conc }}-5 \mathrm{ml} \mathrm{HNO}_{3 \text { conc }}$ ), which was subsequently heated until dryness to eliminate all chloride for the ICP-MS analysis. $20 \mathrm{ml} 1 \mathrm{M} \mathrm{HNO}_{3}$ was added, the undissolved matter (mainly quartz and feldspar, determined by X-ray diffraction) filtered, and the solution was made up to a volume of $50 \mathrm{ml}$ with $1 \mathrm{M} \mathrm{HNO}_{3}$. Determinations for $\mathrm{Si}, \mathrm{P}, \mathrm{Ti}, \mathrm{V}, \mathrm{Cr}, \mathrm{Mn}$, $\mathrm{Co}, \mathrm{Ni}, \mathrm{Cu}, \mathrm{Zn}, \mathrm{As}, \mathrm{Ag}, \mathrm{Cd}$ and $\mathrm{Pb}$ were made on a Hewlett Packard 4500 Inductively Coupled PlasmaMass Spectrometer (ICP-MS). Accuracy was maintained through the inclusion of standard samples (Devos-Franç ois ME-standard). Analytical precision at the $95 \%$ confidence level, determined by replicate analysis (five repetitive analyses for five different samples), was better than $10 \%$. Determinations for $\mathrm{Fe}, \mathrm{Mg}$ and $\mathrm{Al}$ were made from the same solutions by Atomic Absorption Spectrometry (AAS) on a Varian Techtron AA6 spectrometer. Accuracy for AAS is better than 2\%. Analytical precision at the $95 \%$ confidence level, determined by replicate analysis, was better than $2 \%$. Detection limits are at the ppm level for AAS and at the ppb level for ICP-MS, but concentrations were measured at $0.1 \%$ for AAS and at $1 \mathrm{ppm}$ for ICP-MS. Only the elements $\mathrm{Cd}$ and $\mathrm{Ag}$ were measured at the $0.1 \mathrm{ppm}$ level.

\section{Results}

The basic statistics of the geochemical data are given in Table 1. Histograms of the data are given in Fig. 4. Most elements $(n=117)$ show outliers in the histograms, pointing to anomalous samples. The elements As $(n=81), \mathrm{Cd}(n=49)$ and $\mathrm{Pb}(n=95)$ were not always present in concentrations above the detection limit of $1 \mathrm{ppm}$ adopted for this study. Ag was only detected in one sample $(0.2 \mathrm{ppm})$, i.e. in the stratigraphy of the city of Sagalassos. This element is therefore not included in Table 1 and Fig. 4.

To determine the influence of the bedrock on the distribution of elements in the stream sediments, the geochemical data of the samples restricted to those streams that have a single geological substrate or major unit upstream were used to calculate threshold values for these different geological units. Thresholds were derived from arithmetic calculations to $95 \%$ probability $(2 \sigma)$ and are given in Table 2. Samples with element concentrations above the threshold for the specific geological substrate of the sampling locality are considered anomalous. Clear differences are observed between the thresholds of the different lithologies. The threshold for $\mathrm{Mg}, \mathrm{P}, \mathrm{Ti}, \mathrm{Cr}, \mathrm{Mn}, \mathrm{Co}$, $\mathrm{Ni}$ and $\mathrm{Cd}$ are higher in the Lycian nappes. This is normal, as these units comprise basic rocks of the ophiolitic mélange, including chromites. The latter are enriched in the trace elements stated above (Evans, 1993). For the elements $\mathrm{Mn}, \mathrm{Cr}, \mathrm{Co}, \mathrm{Ni}, \mathrm{Cu}$ and $\mathrm{Cd}$, the calculated thresholds in the Bey Dağları limestone massif, the flysch deposits and the Quaternary tuffs are very similar. The Bey Dağları Massif is enriched in $\mathrm{Fe}, \mathrm{P}, \mathrm{Ti}, \mathrm{V}$ and $\mathrm{Pb}$ compared to the flysch and the Quaternary tuffs. The flysch shows lower $\mathrm{Zn}$ and $\mathrm{Pb}$ contents compared to the other units, while the Quaternary tuffs are richer in $\mathrm{Mg}$ and As than the Bey Dağları unit and the flysch. These differences are, however, small. Apart from $\mathrm{Zn}$ and $\mathrm{Cd}$, all thresholds 
Table 4

Principal component analysis of the anomalous samples identified on the territory of Roman Sagalassos

\begin{tabular}{|c|c|c|c|c|}
\hline Factors & 1 & 2 & 3 & 4 \\
\hline & 5.435 & 3.188 & 1.763 & 1.611 \\
\hline \multicolumn{5}{|c|}{ Component loadings } \\
\hline $\mathrm{Mg}$ & 0.876 & 0.393 & 0.110 & 0.192 \\
\hline $\mathrm{Al}$ & -0.691 & 0.148 & 0.392 & -0.398 \\
\hline $\mathrm{Fe}$ & 0.448 & -0.388 & 0.649 & -0.119 \\
\hline $\mathrm{Si}$ & -0.194 & 0.491 & 0.291 & 0.477 \\
\hline $\mathrm{P}$ & -0.600 & 0.488 & 0.103 & 0.284 \\
\hline $\mathrm{Ti}$ & 0.033 & -0.753 & 0.147 & 0.503 \\
\hline $\mathrm{V}$ & 0.081 & -0.880 & 0.276 & 0.198 \\
\hline $\mathrm{Cr}$ & 0.867 & 0.458 & 0.143 & -0.018 \\
\hline $\mathrm{Mn}$ & -0.011 & -0.091 & 0.536 & -0.665 \\
\hline Co & 0.874 & 0.352 & 0.214 & -0.045 \\
\hline $\mathrm{Ni}$ & 0.874 & 0.428 & 0.106 & 0.082 \\
\hline $\mathrm{Cu}$ & -0.722 & 0.556 & 0.165 & 0.053 \\
\hline $\mathrm{Zn}$ & -0.240 & -0.047 & 0.618 & 0.400 \\
\hline $\mathrm{Pb}$ & -0.615 & 0.444 & 0.248 & 0.080 \\
\hline \multicolumn{5}{|c|}{ Variance explained by components } \\
\hline & 5.435 & 3.188 & 1.763 & 1.611 \\
\hline \multicolumn{5}{|c|}{ Percent of total variance explained } \\
\hline & 36.231 & 21.252 & 11.752 & 10.740 \\
\hline
\end{tabular}

are within the normal range of element contents for the different types of geological units on the territory (see Govett, 1983; Evans, 1993). The Zn and Cd contents are significantly higher than normal background levels for these units.

For the presentation and interpretation of the geochemical data from a large district with several major geological units, the method of standardisation according to Govett and Galanos (1974) is used. The data are standardised so that the threshold for each element over each designated major unit and rock type is made equal to zero. All analytical results are standardised according to the relation [(Metal Value - Threshold)/ Threshold*100]. The value used for the threshold in the calculation is that of the particular element for the particular rock unit with which the sample is associated (Govett and Galanos, 1974). Once all values have been standardised, all positive values are considered anomalous and are directly comparable. To be fully effective, different threshold values should be used for the various lithological types within each of the main rock units (Govett and Galanos, 1974). The standardised data for all anomalous samples are given in Table 3.

If the analytical data of the anomalous samples identified through the standardisation procedure are used to calculate Pearson correlations, strong correlations between the elements become obvious. Evidently, samples considered anomalous for one group of elements are not necessarily anomalous for another asso-

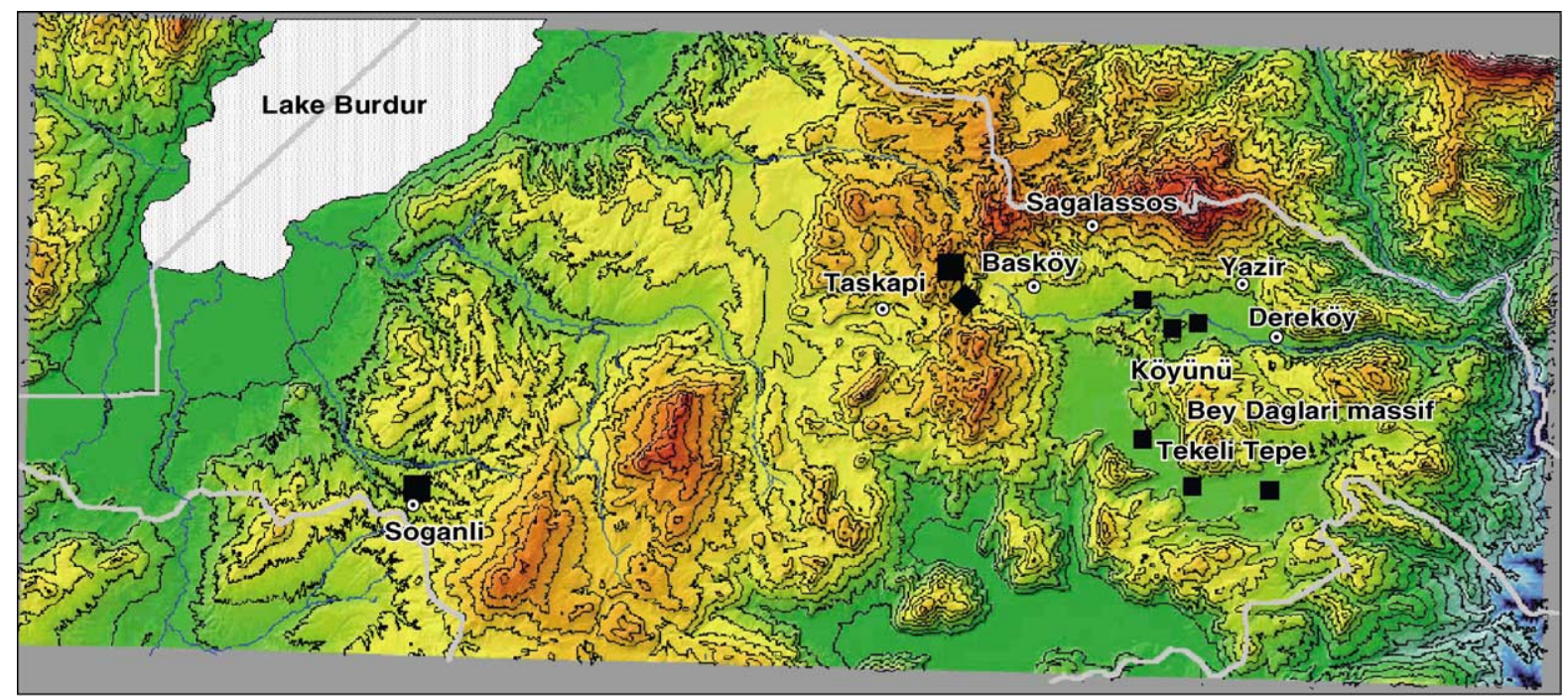

Fig. 8. Geographical location of the samples with anomalous $\mathrm{Mg}, \mathrm{Cr}$, Co and $\mathrm{Ni}$ contents (large squares: $>100 \%$ anomalous, small squares: $<100 \%$ anomalous) and anomalous Fe, Ti and V concentrations (large diamond: $>100 \%$ anomalous, small diamond: $<100 \%$ anomalous). Location of the study area is indicated in Fig. 2. 


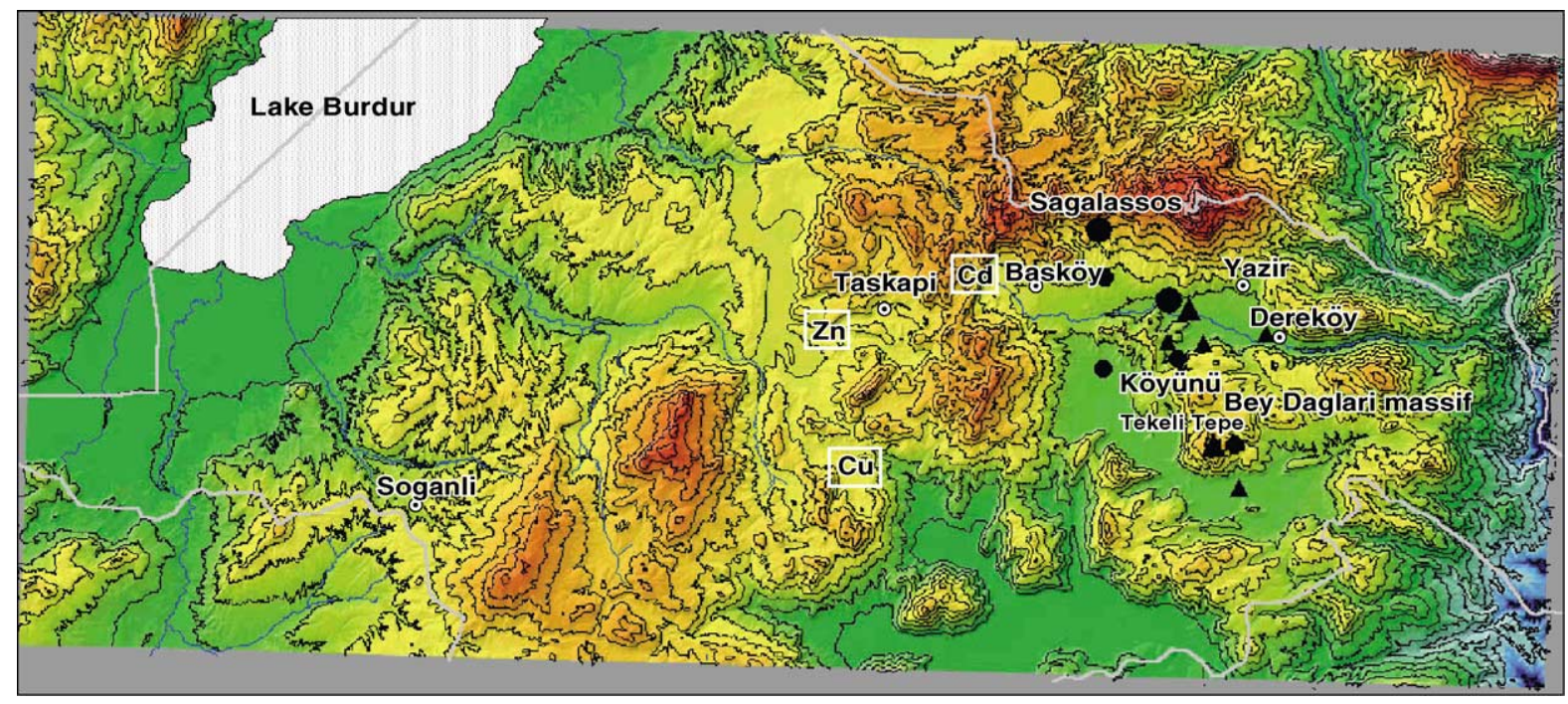

Fig. 9. Geographical location of the samples with anomalous $\mathrm{P}, \mathrm{Cu}$ and $\mathrm{Pb}$ contents (large circles: $>100 \%$ anomalous, small circles: $<100 \%$ anomalous), $\mathrm{Mn}$ anomalies (large triangle: $>100 \%$ anomalous, small triangles: $<100 \%$ anomalous) and anomalous contents in $\mathrm{Zn}, \mathrm{Cd}$ or $\mathrm{Cu}$ (frames). Location of the study area is indicated in Fig. 2.

ciation of elements. This will influence the Pearson correlation factor of all elements for the whole sample population. For the samples considered anomalous in the standardisation procedure $(n=30)$, biplots are made for the element groups $\mathrm{Mg}, \mathrm{Cr}, \mathrm{Co}$ and $\mathrm{Ni}$ (Fig. 5), Fe, T and $\mathrm{V}$ (Fig. 6) and $\mathrm{P}, \mathrm{Pb}$ and $\mathrm{Cu}$ (Fig. 7). In the calculations, the $\log$ is taken for the log-normally distributed elements $\mathrm{Co}, \mathrm{Cr}, \mathrm{Mg}, \mathrm{Mn}, \mathrm{Ni}, \mathrm{P}, \mathrm{Pb}, \mathrm{Ti}$ and V. Principal component analysis of the same data reveals a similar result. Four factors explain a total variance of $80 \%$ (Table 4). A first factor is positively correlated with the $\mathrm{Mg}, \mathrm{Cr}, \mathrm{Co}$ and Ni contents (loading between 0.87 and 0.88 ) and negatively correlated with the $\mathrm{P}, \mathrm{Cu}$ and $\mathrm{Pb}$ contents (loading between -0.60 and -0.72$)$. A second factor is negatively correlated with the $\mathrm{Ti}$ and $\mathrm{V}$ contents (loading between -0.75 and -0.88 ). A third factor reflects the positive correlation between $\mathrm{Fe}, \mathrm{Zn}$ and $\mathrm{Mn}$ contents (loading between 0.64 and 0.73 ) and finally a fourth factor is only significantly correlated with the $\mathrm{Ti}$ and $\mathrm{Zn}$ content (loading 0.40 to 0.50 ).

From the standardised data, it is clear that on the one hand the elements $\mathrm{Mg}-\mathrm{Cr}-\mathrm{Co}-\mathrm{Ni}$ and on the other hand $\mathrm{Fe}-\mathrm{Ti}-\mathrm{V}$ are significantly correlated. Anomalies for these element associations occur in the sampling sites indicated on Fig. 8. The sampling sites which show anomalous values for the $\mathrm{P}-\mathrm{Cu}-\mathrm{Pb}$ content are indicated together with the anomalous $\mathrm{Mn}$ contents and the single anomalous samples for $\mathrm{Zn}, \mathrm{Cu}$ and Cd on Fig. 9.

\section{Discussion}

The anomalous locations for the elements $\mathrm{Mg}, \mathrm{Cr}$, $\mathrm{Co}, \mathrm{Ni}$ on the one hand and for the elements $\mathrm{Fe}, \mathrm{V}$ and $\mathrm{Ti}$ on the other hand are situated in three areas, i.e. the pass from Başköy to Taşkapı $(n=2$ for the $\mathrm{Mg}-\mathrm{Cr}-\mathrm{Co}-\mathrm{Ni}$ group, $n=3$ for the $\mathrm{Fe}-\mathrm{Ti}-\mathrm{V}$ group), around the Bey Dağları Massif $(n=8$ for the $\mathrm{Mg}-\mathrm{Cr}-\mathrm{Co}-\mathrm{Ni}$ group, $n=1$ for the $\mathrm{Fe}-\mathrm{Ti}-\mathrm{V}$ group) and the village of Soğanlı ( $n=1$ for the $\mathrm{Mg}-$ $\mathrm{Cr}-\mathrm{Co}-\mathrm{Ni}$ group). The anomalous values on the pass from Baş köy to Taş kapı coincide with the location of the known chromite and magnetite/chrysotile mineralisation as described earlier. The anomalous values for $\mathrm{Cr}, \mathrm{Mg}, \mathrm{Co}$ and $\mathrm{Ni}$ in the village of Soğanlı could indicate the presence of a similar mineralisation in this area, associated with the basic rocks of the Lycian nappes. However, such mineralisation has not yet been identified. The explanation for the anomalous values around the Bey Dağları Massif is twofold. First of all, the Bey Dağları Massif is not only made up of limestones and shales, 
but also contains olistostrome deposits with a large quantity of basic clasts originating from the ophiolitic mélange (Degryse et al., in press; Muchez et al., in press). If the thresholds defined for the Lycian nappes, containing basic rocks, are used to recalculate the data of the localities around the olistostrome units of the Bey Dağları Massif, the anomalies for $\mathrm{Mg}, \mathrm{Cr}, \mathrm{Co}$ and $\mathrm{Ni}$ do not longer exist (Table 5). Therefore, the first possible interpretation explaining the anomalies around the Bey Dağları Massif is the varying bedrock. Secondly, in the geochemical survey, a mineralisation of magnetite-magnesioferrite associated with chertified shales and limestones was identified at the southern edge of the Bey Dağları Massif around Tekeli Tepe (Fig. 8). It is clear from the archaeological context that this mineralisation has been mined in antiquity. The entire area was covered with slag, bloom (enriched iron products) and other waste products of ancient metalworking. Remains of kilns and hearths can be found, as well as crucibles. Associated ceramics provided a provisional date for the metal working around early Byzantine times, being the 6th to 7th century AD (J. Poblome, personal communication). The bloom and slag samples from the Bey Dağları massif differ mineralogically and chemically from the slag in the city of Sagalassos. The material has a distinct mineralogical composition, which is dominated by the occurrence of magnetite and iron, along with fayalite and wuestite in smaller amounts. The chemical analysis of the ore (mainly magnetite), slag and bloom shows identical high $\mathrm{Fe}$ (up to $80 \%$ ), $\mathrm{Ti}$ (up to $8 \%$ ) and $\mathrm{V}$ (up to $1.5 \%$ ) contents, together with elevated REE, $\mathrm{Zr}, \mathrm{U}$ and Th concentrations (P. Degryse, unpublished data). The distinct chemical composition of the ore

Table 5

Anomalous samples identified around the Bey Dağları Massif by standardising the geochemical data to the threshold value for the Lycian Nappe Complex

\begin{tabular}{lccccr}
\hline Sample & $\mathrm{Fe}$ & $\mathrm{P}$ & $\mathrm{Mn}$ & $\mathrm{As}$ & $\mathrm{Pb}$ \\
\hline SA 01 PDS 25 & 27 & & & & \\
SA 01 PDS 24 & & 46 & 76 & & \\
SA 96 PS 4 & & & 33 & & \\
SA 97 AC 53 & & 12 & & & \\
SA 97 AC 54 & & & & 25 & \\
SA 97 AC 62 & & 19 & 70 & 62 & 87 \\
\hline
\end{tabular}

and metallurgical waste explains the clear geochemical anomaly for $\mathrm{Fe}$, $\mathrm{Ti}$ and $\mathrm{V}$ around this location.

All anomalous values for $\mathrm{P}, \mathrm{Cu}, \mathrm{Pb}$ and $\mathrm{Mn}$ are situated in the excavation layers of the city of Sagalassos itself or around the Bey Dağları Massif (Fig. 9). Anomalous concentrations of these elements are often associated with ancient human activities and occupation (Bintliff et al., 1990). In Sagalassos, these layers are not only anomalous in $\mathrm{P}, \mathrm{Cu}$ and $\mathrm{Pb}$ but also in As (Table 3) and Ag (one sample). High As contents have often been associated with modern pollution (e.g. Swennen and Van der Sluys, 1998; Deckers et al., 2000), but it is apparent from this study that it is also an indicator for past human activities. The Ag anomaly could be due to the use of this precious metal in ancient times. Around the Bey Dağları Massif, apart from the already described metal working site, remains of slag and bloom from iron working have been identified at several locations (Dereköy, Yazır, Köyünü indicated on Fig. 9). It is therefore likely that the anomalous values for $\mathrm{P}, \mathrm{Cu}$, $\mathrm{Pb}, \mathrm{Mn}$ and $\mathrm{As}$ (Table 3) around the Bey Dağları Massif are related to human activity (metallurgy, agriculture) and ancient occupation. It is noteworthy that the geological formation containing the mineralised unit as identified at the metalworking site of Tekeli Tepe is situated in a north-south oriented direction across the Bey Dağları Massif (Degryse et al., in press). This opens perspectives for future exploration for metallurgical sites. Likewise important for future geochemical studies is the identification of the association $\mathrm{P}, \mathrm{Cu}, \mathrm{Pb}, \mathrm{Mn}, \mathrm{As}(\mathrm{Ag})$ as an indicator for ancient human activity (see also Bintliff et al., 1990). It is moreover certain that these signatures are not due to modern contamination or pollution. Several samples were taken from stream sediments in modern villages in the area (these were not taken into account for the calculation of the thresholds for the different lithological units) and did not show any anomalous value for any element.

For the samples showing an anomaly for $\mathrm{Zn}$ or $\mathrm{Cu}$ or $\mathrm{Cd}$, there seems to be no evident relation with ancient ore extraction or metalworking. However, the association of $\mathrm{Zn}, \mathrm{Cu}$ and $\mathrm{Cd}$ anomalies is often used in prospection for $\mathrm{Zn}$ deposits (Evans, 1993). It is clear that the $\mathrm{Zn}$ and $\mathrm{Cd}$ contents in the area are above what is described as a normal abundance for the known lithologies (Govett, 1983; Evans, 1993). 


\section{Conclusion}

The geochemical anomalies identified on the territory of the ancient city of Sagalassos are explained by the presence of mineralisations and ancient human activity. The association of anomalous contents of $\mathrm{Mg}-\mathrm{Cr}-\mathrm{Co}-\mathrm{Ni}$ points to mineralisation related with the basic rocks of the Lycian nappes, while the association $\mathrm{Fe}-\mathrm{V}-\mathrm{Ti}$ indicates the presence of iron mineralisations. The latter were economical in ancient times, as an iron-working site was identified. Finally, the association $\mathrm{P}-\mathrm{Cu}-\mathrm{Pb}-\mathrm{Mn}-\mathrm{As}(\mathrm{Ag})$ indicates ancient human activity and occupation and is highly relevant for ancient metallurgy. These geochemical results have practical implications for archaeologists. Through the identification of anomalous $\mathrm{P}-\mathrm{Cu}-\mathrm{Pb}-$ $\mathrm{Mn}-\mathrm{As}$ (Ag) contents at a certain position in the excavation stratigraphy, ancient occupation or working (agricultural, metallurgical) can be identified.

\section{Acknowledgements}

The reviewers I. Joosten and R. Salminen and the editor-in-chief R. Swennen are sincerely acknowledged for their constructive comments on the manuscript. S. Lens is kindly thanked for chemical analyses. The results of this study were published with the support of the 'Universitaire Stichting van België' for the illustrations ("Met de steun van de Universitaire Stichting van België voor de illustraties"). This research is supported by the Belgian Programme on Interuniversitary Poles of Attraction (IUAP 4/12 and 5/09) initiated by the Belgian State, Prime Minister's Office, Science Policy Programming. This text also presents the results of the Concerted Action of the Flemish Government (GOA 02/2). M. Waelkens is L. Baert-Hofman Professor of Eastern Mediterranean Archaeology. Scientific responsibility is assumed by the authors.

\section{References}

Bintliff, J.L., Gaffney, C., Waters, A., Davies, B., Snodgrass, A., 1990. Trace metal accumulations in soils on and around ancient settlements in Greece. In: Bottema, S., Entjes-Nieborg, G., Van Zeist, W. (Eds.), Man's Role in the Shaping of the
Eastern Mediterranean Landscape. Proceedings of the INQUA/BAI Symposium on the Impact of Ancient Man on the Landscape of the Eastern Mediterranean Region and the Near East. Balkema, Rotterdam, pp. 159-172.

Bintliff, J.L., Davies, B., Gaffney, C., Snodgrass, A., Waters, A., 1992. Trace metal accumulations in soils on and around ancient settlements in Greece. In: Spoerry, P. (Ed.), Geoprospection in the archaeological landscape. Oxbow Monograph, vol. 18, pp. 9-24. Oxford.

Cleere, H., 1976. Ironmaking. In: Strong, D., Brown, D. (Eds.), Roman Crafts. Duckworth, London, pp. 127-142.

Deckers, J., Laker, M., Vanherreweghe, S., Vanclooster, M., Swennen, R., Cappuyns, V., 2000. State of the art on soil-related geomedical issues in the World. In: Lag, J. (Ed.), Geomedical problems in developing countries. The Norwegian Academy of Science and Letters, Oslo, pp. 23-42.

Degryse, P., 2001. Mineral resources and their use on the territory of Sagalassos (SW Turkey). PhD Thesis. Katholieke Universiteit Leuven, Leuven.

Degryse, P., Muchez, Ph., Sintubin, M., Clijsters, A., Viaene, W., Dederen, M., Schrooten, P., Waelkens, M., in press. The geology of the area around the ancient city of Sagalassos (SW Turkey). In: Waelkens, M., Poblome, J. (Eds.), Sagalassos VI. Acta Archaeologica Lovaniensia Monographiae 12. Leuven Univ. Press, Leuven.

Dilek, Y., Rowland, J.C., 1993. Evolution of a conjugate passive margin pair in Mesozoic Southern Turkey. Tectonics 12, 954-970.

Evans, A.M., 1993. Introduction to mineral exploration. Blackwell, London. 396 pp.

Govett, G.J.S., 1983. Handbook of exploration geochemistry. Rock geochemistry in mineral exploration, vol. 3. Elsevier, Amsterdam. 459 pp.

Govett, G.J.S., Galanos, D.A., 1974. Drainage and soil geochemical surveys in Greece: use of standardized data as an interpretative procedure. Transactions of the Institution of Mining and Metallurgy Section B83, 99-111.

Hawkes, H.E., 1976. The downstream dilution of stream sediment anomalies. Journal of Geochemical Exploration 6, 345-358.

Joosten, I., Jansen, J.B.H., Kars, H., 1998. Geochemistry and the past: estimation of the output of a Germanic iron production site in the Netherlands. Journal of Geochemical Exploration 62, $129-137$.

Kazanci, N., Erol, O., 1987. Sedimentary characteristics of a Pleistocene fan-delta complex from Burdur basin, Turkey. Zeitschrift für Geomorphologie N.F. 31, 261-275.

Kucha, H., Waelkens, M., Viaene, W., Laduron, D., 1995. Mineralogy, geochemistry and phase equilibria as tracers of the technology of iron (steel) making at Sagalassos during the Roman period. In: Waelkens, M., Poblome, J. (Eds.), Sagalassos III. Acta Archaeologica Lovaniensia Monographiae, vol. 7. Leuven Univ. Press, Leuven, pp. 273-291.

Mitchell, S., 1999. Greek epigraphy and social change. A study of Romanization of South-West Asia Minor in the third century $\mathrm{AD}$, Proceedings of the XI Congresso Internazionale di epigrafia greca e latina. Rome, Italy.

Mitchell, S., 2000. The settlement of Pisidia in late Antiquity and 
the Byzantine period: methodological problems. In: Belke, K., Hild, F., Koder, J., Soustal, P. (Eds.), Byzans als Raum. Zu Methoden und Inhalten der historischen Geographie des östlichen Mittelmeerraumes. Veröffentlichungen der Kommission für die Tabula Imperii Byzantini 7. Denkschriften, vol. 283. Österreichische Akademie der Wissenschaften, Vienna, pp. 139-152.

MTA, 1997. Geological Survey of Turkey Geological Maps, vol. 4. MTA, Ankara, Isparta.

Muan, A., Osborn, E.F., 1965. Phase equilibria among oxides in steelmaking. Addison-Wesley Publication, Reading, Massachusetts. 113 pp.

Muchez, Ph., Lens, S., Degryse, P., Callebaut, K., Dederen, M., Hertogen, J., Joachimski, M., Keppens, E., Ottenburgs, R., Schroyen, K., Waelkens, M., in press. Petrography, mineralogy and geochemistry of the rocks in the area of the archaeological site of Sagalassos, SW Turkey. In: Waelkens, M., Poblome, J. (Eds.), Sagalassos VI. Acta Archaeologica Lovaniensia Monographiae 12. Leuven Univ. Press, Leuven.

Paulissen, E., Poesen, J., Govers, G., De Ploey, J., 1993. The Physical Environment at Sagalassos (Western Taurus, Turkey). A Reconnaissance Survey. In: Waelkens, M., Poblome, J. (Eds.), Sagalassos II. Acta Archaeologica Lovaniensia Monographiae, vol. 6. Leuven Univ. Press, Leuven, pp. 229-240.

Poisson, A., 1975. Geological Map of the Isparta Area. Centre National de Recherche Scientific, Paris.

Poisson, A., 1977. Recherches géologiques dans les Taurides occidentales. Thèse de Doctorat d'Etat, Université d'Orsay, Paris.

Poisson, A., Akay, E., Dumont, J.F., Uysal, S., 1984. The Isparta Angle: a Mesozoic paleorift in the Western Taurides. In: Tekeli, O., Goncüoglu, C. (Eds.), Geology of the Taurus Belt. Proceedings of the International Symposium on the Geology of the Taurus Belt. MTA, Ankara, pp. 11-26.

Robertson, A.H.F., 1993. Mesozoic-Tertiary sedimentary and tectonic evolution of Neotethyan carbonate platforms, margins and small ocean basins in the Antalya Complex, southwest Turkey. In: Frostick, L.E., Steel, R.J. (Eds.), Tectonic Controls and Signatures in Sedimentary Successions. Special Publication of the
International Association of Sedimentologists, vol. 20. Blackwell, Oxford, pp. 415-465.

Swennen, R., Van der Sluys, J., 1998. Zn, Pb, Cu and As distribution patterns in overbank and medium-order stream sediment samples: their use in exploration and environmental geochemistry. Journal of Geochemical Exploration 65, 27-45.

van Zeist, W., Woldring, H., Stapert, D., 1975. Late Quaternary Vegetation and Climate of Southwestern Turkey. Palaeohistoria $17,55-143$.

Waelkens, M., in press. Romanization in the East. A case study: Sagalassos of Pisidia (SW Turkey). Istanbuler Mitteilungen 52.

Waelkens, M., Paulissen, E., Vanhaverbeke, H., Öztürk, I., Decupere, B., Ekinci, H.A., Vermeersch, P.M., Poblome, J., Degeest, R., 1997. The 1994 and 1995 Surveys on the Territory of Sagalassos. In: Waelkens, M., Poblome, J. (Eds.), Sagalassos IV. Acta Archaeologica Lovaniensia Monographiae, vol. 9. Leuven Univ. Press, Leuven, pp. 11-102.

Waelkens, M., Paulissen, E., Vermoere, M., Degryse, P., Celis, D., Schroyen, K., De Cupere, B., Librecht, I., Nackaerts, K., Van Haverbeke, H., Viaene, W., Muchez, Ph., Ottenburgs, R., Deckers, S., Van Neer, W., Smets, E., Govers, G., Verstraeten, G., Steegen, A., Cauwenbergs, K., 1999. Man and Environment in the Territory of Sagalassos. Quaternary Science Reviews $18,697-710$.

Waelkens, M., Vanhaverbeke, H., Paulissen, E., Poblome, J., Reyniers, J., Viaene, W., Deckers, J., Decupere, B., Van Neer, W., Ekinci, H.A., Erbay, M.O., 2000a. The 1996 and 1997 Survey Seasons at Sagalassos. In: Waelkens, M., Loots, L. (Eds.), Sagalassos V. Acta Archaeologica Lovaniensia Monographiae, vol. 11. Leuven Univ. Press, Leuven, pp. 17-216.

Waelkens, M., Sintubin, M., Muchez, Ph., Paulissen, E., $2000 \mathrm{~b}$. Archaeological, geomorphological and geological evidence for a major earthquake at Sagalassos (SW Turkey) around the middle of the seventh century AD. In: McGuire, B., Griffiths, D., Stewart, I. (Eds.), The archaeology of geological catastrophes. Geological Society of London Special Publications, vol. 171. Geological Society of London, London, pp. 373-383. 